\title{
Eliminating Violence against Women in Pacific through Multi-Track Diplomacy
}

\author{
Sherly Mega Putri ${ }^{1} \&$ Elisabeth A. Satya Dewi ${ }^{2}$ \\ ${ }^{1}$ Department of International Relations, Parahyangan Catholic University, Indonesia \\ sherlymgptr@gmail.com \\ ${ }^{2}$ Department of International Relations, Parahyangan Catholic University, Indonesia \\ elisabeth.dewi@unpar.ac.id
}

\begin{abstract}
Humanitarian issue that often raised as a problem for developing countries, is often likely linked to gender issue. Having labeled as a region with the highest violence data prevalence, Pacific Islands countries possess assorted factors that tolerates the practice of gender dominance and discrimination amongst their societies. Responding this phenomenon, the governments in Pacific Islands countries are oftentimes receiving assistance from other international relations actors, in which one of them is UN Women. With the support from Australian government, this UN body assist numerous institutions from various level in making the effort to eliminate violence against women as the most protrude form of gender based discrimination in Pacific. Involvement of other parties from diverse groups indicates the relations between actors of Multi-Track Diplomacy with the program initiated by UN Women. Using theory of Multi-Track Diplomacy and concept of Gender-Based Violence, this research identifies the participation and contribution made by a total of nine tracks in responding to violence against women issue in the Pacific. Such response itself is one of the world peace endeavors, which is also the ultimate purpose of Multi-Track Diplomacy. Result of this response shaped in their participation and contribution within variety of programs under Pacific Fund.
\end{abstract}

Keywords: Pacific, gender equality, foreign aids, Multi-Track Diplomacy, peacemaking.

ABSTRAK

Isu kemanusiaan yang sering menjadi masalah di negara berkembang, kerap bersinggungan dengan isu gender. Memiliki predikat sebagai kawasan dengan prevalensi data kekerasan tertinggi, negara-negara di Pasifik memiliki berbagai faktor penyebab yang memaklumi praktik dominansi dan diskriminasi gender dalam masyarakatnya. Menanggapi fenomena ini, pemerintah di negara-negara Pasifik kerap mendapatkan bantuan dari aktor hubungan internasional yang lain, salah satunya adalah UN Women. Dengan dukungan dari Pemerintah Australia, badan PBB tersebut membantu berbagai pihak dari beragam kalangan di Pasifik untuk mewujudkan upaya mengeliminasi kekerasan terhadap perempuan sebagai suatu bentuk ketidaksetaraan berbasis gender paling menonjol di kawasan Pasifik. Keterlibatan berbagai pihak dari beragam kalangan menunjukkan adanya keterkaitan antara aktor dalam Diplomasi Multi-Jalur dengan program yang diinisiasi oleh UN Women. Menggunakan teori Diplomasi Multi-Jalur dan konsep Kekerasan Berbasis Gender, penelitian ini mengidentifikasi keterlibatan kesembilan aktor Diplomasi Multi-Jalur dalam merespons isu kekerasan terhadap perempuan di Pasifik. Respons tersebut menjadi salah satu upaya perwujudan perdamaian dunia, yang juga menjadi tujuan akhir Diplomasi MultiJalur itu sendiri. Hasil dari respons tersebut berwujud partisipasi serta kontribusi mereka dalam lima program di bawah Pacific Fund.

Kata kunci: Pasifik, kesetaraan gender, bantuan luar negeri, Diplomasi Multi-Jalur, upaya perdamaian. 


\section{Introduction}

Bearing the status as non-traditional issue of international relations, gender equality issues have increasingly matured since its emergence in the 1990s. Unlike the traditional international relations issues that prone to the classic state security values and war-related interests, social phenomenon is getting the worldwide attention. Nevertheless, gender discrimination is still prevalent.

Case in point within Asia is the fact that the number of women whom politically participated in the Indonesian parliament is measured to have imbalanced ratio compared with the nation's female citizen. ${ }^{1}$ This occurrence shows that even we already have the Convention on Elimination of All Form of Discrimination Against Women (CEDAW) applied globally, gender discrimination still exists. This leads to the gruesome facts that another branch of global problem within gender discrimination, also including gender-based violence.

There are $50 \%$ women experiencing sexual violence around the globe, with Pacific Islands countries holds the title of region with the highest prevalence; according to the data from UN Women in 2017, with the extend of $68 \%$ women as victims, ${ }^{2}$ which is higher than Middle East and North Africa with nearly 40 to $60 \%$ women as sexual harassment victims. ${ }^{3}$ This figures showed that gender-based violence is one

\footnotetext{
${ }^{1}$ Valentina, A. M., \& Dewi, E. A. S. Implementasi CEDAW tentang Penghapusan Diskriminasi Perempuan: Studi Kasus Pemilu di Indonesia Tahun 2009 dan 2014. Jurnal Ilmiah Hubungan Internasional. ISSN: 24068748

${ }^{2}$ UN Women Field Office of Asia and the Pacific. (2017, August 17). Ending Violence against Women Programme, 2017. Retrieved from http://asiapacific.unwomen.org/en/countries/fiji/endin g-violence-against-women

${ }^{3}$ UN Women. (2018, December 10). Facts and figures: Ending violence against women, 2018. Retrieved from http://www.unwomen.org/en/whatwe-do/ending-violence-against-women/facts-andfigures
}

of the most concerning form of gender discrimination, particularly in the Pacific. In response to the rampant GBV phenomenon, varied international relations actors offering their hands under the spirit of equality and peace.

This paper intent to delve deeper on the correlation between issue of violence against women with the response of international relations actors; identifying their roles and exertion in line with the endeavors of world peace preservation. This objective is linked to the implementation of Multi-Track Diplomacy by Australian Government and UN Women, in responding to the gender discrimination issues in Pacific. This writing argues on how Multi-Track Diplomacy can be applied to humanitarian issue, such as gender based violence.

To narrow the focus; Samoa, Solomon Islands, and Tonga will be the three focal countries to be observed. These three Pacific countries are chosen based on the variety of programs being held under participation of many international relations actor within 'Pacific Fund' by UN Women, which shown the distinctive actor of each tracks in the MultiTrack Diplomacy. Using qualitative research method, a descriptive analysis is conducted to analyze the program that marked with project started in 2013 and ended with project that was held in 2017.

\section{Theoretical Framework}

As the analysis lens in understanding the problem, Gender-Based Violence concept and Multi-Track Diplomacy theory are applied to this paper. The first concept is being used to understand further the types of violence occurred globally, while the second theory is being used based to point out the mapping of collective efforts from distinctive international relations actors within the nine tracks. 


\section{A. Gender-Based Violence}

Theoretically, Gender-Based Violence (GBV) concept is a combination of several other disciplines that further explains on how violent acts occurred as a response towards the gender of someone. ${ }^{4}$ With various background factors such as expressive tension, impulse force, societal legitimation, or observed behavior, GBV applied in numerous circumstances as well, from physical to the practice of religion. In this context, types of violence being observed only revolves around: (1) physical: kicking, burning, dragging by hair, etc.; (2) sexual: rape, forced penetration, sexual slavery, unwanted sexual comments, etc.; (3) verbal: yelling, hurtful jokes, spreading rumors, catcalling, etc.; (4) social: excessive possessiveness, threats of harm, stopping a person to see their friends and family, etc.; and (5) financial: forcing someone to quit a job, controlling an individual's finance, withholding money for essential items, etc. ${ }^{5}$ These five types of violence are the most common forms to be happened to women worldwide.

\section{B. Multi-Track Diplomacy}

Essentially, as a part of diplomacy that often involves official procedure from government, Multi-Track Diplomacy (MTD) is the implication of other parties outside government system to implement the work of diplomacy itself. Coined by U.S. Diplomat John McDonald, this type of diplomacy has nine distinctive actors positioned as nine tracks, collectively worked for peacemaking.

\footnotetext{
${ }^{4}$ United Nations General Assembly. Convention on the Elimination of All Forms of Discrimination against Women. December 1979

${ }^{5} \mathrm{UN}$ Women. How to Design Projects to End Violence Against Women and Girls: A step-by-step guide to taking action (pp. 32-34). Fiji: UN Women Pacific Multi-Country Office. 2015.
} 
Image 1. Multi-Track Diplomacy Matrix

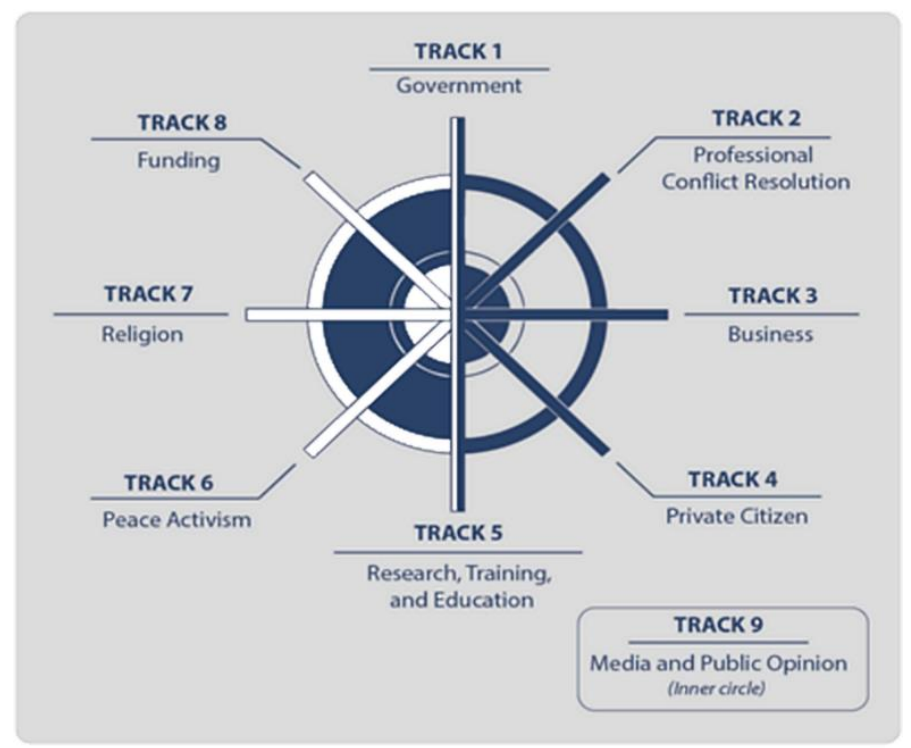

Source: Institute of Multi-Track Diplomacy ${ }^{6}$

The tracks itself consists of: (1) Government, peacemaking through diplomacy; Nongovernmental/ Professional; peacemaking through conflict resolution; (3) Business, peacemaking through commerce; (4) Private Citizen; peacemaking through personal involvement; (5) Research, Training, and Education, peacemaking through learning; (6) Activism, peacemaking through advocacy; (7) Religion, peacemaking through faith in action; (8) Funding, peacemaking through providing resource; and (9) Communications and the Media, world peace through information. ${ }^{7}$ All these nine tracks shall create a huge impact when worked together as a system; both when nine tracks simultaneously used or partially worked together.

\footnotetext{
${ }^{6}$ Institute of Multi-Track Diplomacy Official Website. (2018, February 23). What is Multi-Track Diplomacy? Retrieved from http://imtd.org/about/what-is-multi-track-diplomacy/

${ }^{7}$ Louise Diamond and John McDonald. Multi Track Diplomacy: A Systems Approach to Peace, Third Edition. West Hartford: Kumarian Press. 1996.
}

\section{Gender-Based Violence in Pacific}

The data reckoned in the Pacific showed that GBV is the most critical form of gender inequality in the region, particularly violence against women (VAW). Australia National Committee for UN Women stating, intimate partner violence data prevalence ranging from 2012 to 2015, in Tonga reached the amount of $33 \%$, while sexual violence is at $17 \%$. Samoa reaching $41 \%$ for intimate partner violence and $20 \%$ for sexual violence, while Solomon Islands topped the other countries with $46 \%$ of intimate partner violence and $55 \%$ sexual violence. ${ }^{8}$ Worth to keep in mind, that this data only reflects the reported events.

This percentage became the evidence of how the acts of beating, coerced intercourse, heavy insults, belittling an individual, controlling financially, and other form of VAW has degrading the rights and dignity of most female

\footnotetext{
${ }^{8}$ Bricknell, R. Eliminating Violence against Women in Asia Pacific: It's All of Our Responsibility (pp. 6). UN Women National Committee Australia. 2015.
} 
population in these three countries. The proof disclosed in a survey that says $60 \%$ of survivors claimed that their health is affected both physically and mentally by the VAW acts. ${ }^{9}$ Socially, survivors also find difficulty in accessing justice for them. In Tonga, most of the victims are unaware that the authorities actually serving for them, as they do not believe the police officers fully comprehend what kind of situation the survivors had to go through. ${ }^{10}$ Consequently, the society are not familiar with the violence-related help service access, both as survivor or witness.

Efforts from the government of respective countries in tackling such issues are seen with the establishment of several actions, such as Family Health and Safety Study in Samoa ${ }^{11}$ and Solomon Islands ${ }^{12}$, National Policy on Gender and Development in Tonga ${ }^{13}$, as well as building partnership with non-governmental organizations (NGO) and forming certain special task forces to find the best resolutions. Nevertheless, the aforementioned $68 \%$ victim percentage still becoming the real obstacle to combat VAW. Moreover, the entrenched notion in common society about gender stereotype also contribute to the practice of dominance and violence. Social construction in Pacific that acknowledging the

\footnotetext{
${ }^{9}$ Pacific Community. Samoa Family Health and Safety Study (pp. 74). Noumea: Secretariat of the Pacific Community. 2006.

${ }^{10}$ Fairbairn-Dunlop, P., Lievore, D. Pacific Prevention of Domestic Violence Programme: Tonga Report. Wellington: PPDVP. 2007.

${ }^{11}$ Pacific Women. (2018, February 23). Samoa

Family Health and Safety Study, 30 December 2006.

Retrieved from

https://pacificwomen.org/research/samoa-familyhealth-and-safety-study/

12 National Parliament of Solomon Islands. (2018, February 23). Parliament Passes the Family Protection Bill 2014, 2014. Retrieved from http://www.parliament.gov.sb/index.php?q=node/819 ${ }^{13}$ Ma'a Fafine mo e Famili Tonga. (2018, February 23). National Study on Domestic Violence for Tonga, 2010. Retrieved from https://mfftonga.wordpress.com/2012/08/27/nationalstudy-on-domestic-violence-for-tonga/
}

nature hierarchy of putting women as the more inferior, encouraging social legitimation for men to have special privileges on many life aspects. In this context, the privileges deliver women to act, dress, and think as humble as possible, in order to not causing unwanted attention or set their position in a higher level than men.

This kind of condition is not a simple situation to be handled by government officials. Even the authority has to develop their performance in order to gain more trust from the GBV victims - both men and women -, in regards of reporting, and improve the relationships with civil society. ${ }^{14}$ Hence, using another approach is important to be closer with their own people. In finding the suitable approach, government then able to seek and receive assistance from external parties.

\section{Assistance from External Parties}

Responding to the insignificant response despite the efforts being given by governments, foreign assistances from outside the Pacific countries are more than welcomed. In this case, UN Women and Australian Government are offering their concerns and resolutions.

As the gender equality and women empowerment body in the UN system, UN Women has worked for years in accelerating the needs of women and eliminate all forms of discrimination. It has spread its office around the world and helping governments from various region to implement the CEDAW. In Pacific itself, UN Women has opened the sub-region office in Suva, Fiji. This office then covering 15 Pacific Islands countries with six core concerns; which are (1) access to economic opportunities; (2) political participation; (3) climate change; (4) conflicts; (5) HIV/AIDS; and (6) VAW. ${ }^{15}$ The

\footnotetext{
${ }^{14}$ Beverly Turnbull. Independent Evaluation Report. Wellington: PPDVP. 2011.

${ }^{15}$ UN Women Asia and Pacific. (2018, March 16). Frequently Asked Questions, 2010-2018. Retrieved
} 
last issue in particular, have several strategic plans and trust funds in support.

One of the trust funds UN Women Pacific holds to reaching out women in Pacific is Pacific Regional Ending Violence against Women and Girl Fund, or Pacific Fund in short. Since 2009, this fund was designed to fulfill the needs of Pacific Islands countries as well as their organizations and networks in effort of gender equality as well as eliminating VAW. The focused priorities of this fund are preventing VAW and girls, expanding access to services for survivors, as well as advocacy and lobbying for legislative and policy change and implementation. ${ }^{16}$ In making the priorities into realization, Pacific Fund provides not only financial support, but also technical assistance.

Hence, aside from grants, main components from this trust fund include capacity building, resource development, supervising, and evaluation as well. These assistances are addressed to all social levels, from local, national, to regional ones. Receiver of the grants itself are invited from all sectors, both government bodies to civil society organizations, such as NGO, youth community, or even individual citizen. The candidates of grantees are expected to send a proposal in firsthand, then joining selection process by UN Women team before executing their VAW-related project.

After officially entering the list of grantees, the receivers then completing series of training. Technical training and sharing session with fellow Pacific Fund grantees are expected to give another understanding of VAW from other perspective, as well as promoting communitybased approach. This approach then applied to help the grantees and their project to reach the grass root level. Grantees of Pacific Fund are not limited to only receive funding from $\mathrm{UN}$

from

http://asiapacific.unwomen.org/en/countries/fiji/faq

${ }^{16}$ UN Women. Pacific Fund Project Brief (pp. 6). Suva: UN Women Fiji MCO. 2015.
Women, but also allowing them to receive support from other organizations or funding agencies to join the effort in eliminating VAW. Various financial supporters are welcomed to join the list, but the Australia Government became the biggest donor of Pacific Fund.

Committed to pursue gender equality across international agenda, Australian Government has explicitly made gender equality and women empowerment as one of its national interests, and the cause of its aid work and economic diplomacy pillar. ${ }^{17}$ Managed under Department of Foreign Affairs and Trade (DFAT), the Gender Equality and Women's Empowerment Strategy become the piece of authentic statement by Australian Government regarding commitment and interest to gender equality. As the $6^{\text {th }}$ largest donor of UN Women, ${ }^{18}$ Australian Government also taking the VAW issue in Pacific into account. One of the implemented actions is becoming the major donor of one of UN Women's trust fund, Pacific Fund. The structure of Pacific Fund can be seen below:

\footnotetext{
${ }^{17}$ Australia Department of Foreign Affairs and Trade. Gender Equality and Women's Empowerment Strategy (pp. 2). Barton: Commonwealth of Australia, DFAT. 2016.

${ }^{18}$ UN Women. (2018, July 18). Australia and UN Women reaffirm partnership, January 192017. Retrieved from http://www.unwomen.org/en/news/stories/2017/1/ann ouncer-australia-and-un-women-reaffirm-partnership
} 
Image 2. Pacific Fund flow structure

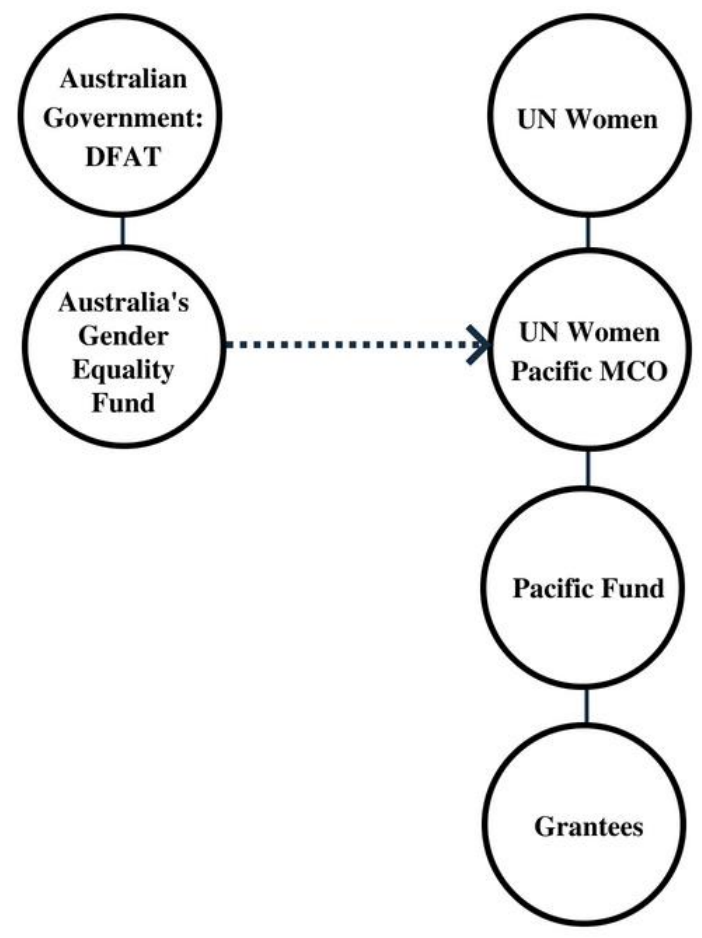

Source: Processed by Author

\section{Programs within Pacific Fund}

Within the year of 2013 to 2017, UN Women officially published "From Policy to Action: Ending Violence against Women and Girls in the Pacific" as the flagship five-year program with financial support largely from Pacific Fund. Plainly, Australian Government, UN Women, and grantees of Pacific Fund worked together as one within this program to accelerate the endeavors of combating VAW in Pacific, through multiple smaller scale projects that oriented to reach the community at the grass root level.

\section{"24-Hours Helpline" in Samoa}

In April 2013, Samoa Victim Support Group (SVSG) used the grants from Pacific Fund to open the official helpline service for GBV survivors in Samoa. ${ }^{19}$ Runs for 24 hours, this service is available nationally to reach the survivors even in remote areas. Within the first five months since its establishment, SVSG receives 1.764 phone calls; 83 calls amongst them are threatening domestic violence related cases, from respondents approximately ranging from 14 to 80 years old. ${ }^{20}$

Playing their role as the Track 2, SVSG also provide phone counseling, crisis center, emergency evacuation for mother and children, references to Domestic Violence Unit of Samoan

\footnotetext{
${ }^{19}$ UN Women Asia and the Pacific. (2018, May 11) Samoan helpline save lives, 17 November 2013. Retrieved from http://asiapacific.unwomen.org/en/news-andevents/stories/2013/11/samoan-helpline-saves-lives ${ }^{20}$ Ibid.
} 
Police, and mediation service. Track 4 and Track 6 are making this program runs accordingly; as SVSG assisted by 25 trained counselors in handling the phone counseling, and 400 area representatives located in 166 Samoa focal points helps to link the victims with the services they deserves. ${ }^{21}$ Digicel and Bluesky, two telecommunication companies in Samoa, holds an important role as the Track 3, to ensure the helpline access reached through smaller areas, with mobile phone provision and excellent phone network. ${ }^{22}$ Participation of the various actors with their respective resources displayed how the collective concerns and efforts of humanitarian issues can bring massive impact when conducted together.

From the implementation of this program, it can be seen that MTD actors involved are; Nongovernmental/ Professional (Track 2), represented by SVSG; Business (Track 3), represented by Digicel and Bluesky; Private Citizen (Track 4), represented by 400 area representatives; and Activism (Track 6), represented by 25 trained counselors.

\section{"Rehabilitation and training for violence perpetrators" in Solomon Islands}

Not only focusing on the survivors of violence, Correctional Services of the Solomon Islands (CSSI) is putting their attention to the convicted offenders. Realizing that these perpetrators are merely human with remorse, as well as witnessing how the detainee then dejected from their past behavior, encourage CSSI to help them reflects. Note to consider as well, that they will eventually come back to the society after their term of punishment terminated.

CSSI as the Track 1 facilitates rehabilitation program alongside series of anti-violence

\footnotetext{
${ }^{21}$ UN Women, “Pacific Fund Project Brief", pp. 6. ${ }^{22}$ Ibid.
}

training and innovative courses since 2013. ${ }^{23}$ Detainees were given sessions of seminar by several numbers of volunteers filling their role as Track 6. Thereafter, UN Women Pacific playing their role as Track 2 with useful courses in increasing the creativity and capabilities of detainees to resume their life after sentence.

Collaboration between the three actors underlining idea of the importance in understanding perpetrators as a potential target group that needs to be embraced. The Track 2 and Track 6 that value the progress of breaking the violence cycle drove them in educating the offenders to be more aware of gender discrimination issue. The rehabilitation and training program giving them another chance in reshaping their mindset.

From the implementation of this program, it can be seen that MTD actors involved are; Government (Track 1), represented by CSSI; Professional (Track 2), represented by UN Women Pacific; and Activism (Track 6), represented by volunteer of training and courses.

\section{"Setting the stage to break the cycle of violence" in Solomon Islands}

Realizing that children in school ages potentially become the future victims or even witnesses, Solomon Islands Family Support Centre (FSC) initiating a play to depict how violence should never be tolerated and we should never stay silence about it. In early of 2017, the Advocacy Unit of FSC partnering with eight schools in Honiara, Solomon Islands, to organize a drama performance with VAW in family as the theme. ${ }^{24}$

\footnotetext{
${ }^{23}$ United Nations. (2018, May 11). Solomon Islands: Uprooting Violence against Women, 27 February 2015. Retrieved from https://www.youtube.com/watch?v=cO3q86_K6oM ${ }^{24}$ Lauretta Ah Sam. (2018, May 7). Setting the stage to break the cycle of violence: theatre as an advocacy tool for youth in Solomon Islands, 7 February 2017. Retrieved from http://asiapacific.unwomen.org/en/news-and-
} 
Due to the fact that children who witness violent act at home are likely to copy the behavior as an adult in the future, the children need to learn that negative activity as seen in VAW practice should not be embedded as common logic.

Taking their role as Track 2, FSC made performing arts as a more effective visualization preference in delivering the anti-violence message. Partnering with locals in Honiara, the trained actors in this drama transformed into actors of Track 4. Consists of five persons, these locals are actually participants of GBV awareness training. The training later become important for them in facilitating discussion session for the students after the drama played.

Combination of drama and discussion become the unconventional method in addressing VAW to the youth. As a human being in their early phase of life, children absorbed many things happened in their surroundings. Therefore, the role of older figure inculcating humanity preservation values to them is essential, as acknowledging the complex concept might not be easily accepted. This kind of thought is what drives the schools to take their roles in Track 5 to provide the education of VAW, with the help of FSC and local actors with the drama play.

From the implementation of this program, it can be seen that MTD actors involved are; Nongovernmental/ Professional (Track 2), represented by FSC; Private Citizen (Track 4), represented by five local actors; and Research, Training, and Education (Track 5), represented by eight schools in Honiara.

\section{"Male Advocacy Training on Ending Violence against Women and Girls" in Tonga}

Ever since its establishment in 2014, The Woman and Children Crisis Centre (WCCC) has been conducting numerous gender sensitive

events/stories/2017/02/setting-the-stage-to-break-thecycle-of-violence> event to raise the awareness whilst designing program that implemented gradually as well. Supported financially by Pacific Network against Violence Against Women (PNAVAW), WCCC as Track 2 hosting a four days intensive training in August 2017, including 20 male civilians as participant. In separate days during this training, the participants were given distinct theme to be discussed, facilitated by experts. ${ }^{25}$ The topics include; (1) VAW and children; (2) justification of culture and religion in violence practice; (3) coercive control; and (4) correlation between men and sexual relationships.

Rev. Dr. Katoanga acting as Track 7 as the representative of Church Leader of Tonga, simultaneously acted as one of the facilitator on the first day, deliver the subject of VAW and children. ${ }^{26}$ On his session, Dr. Katoanga used his role of a religious figure to convey the message of anti-violence, with the analogy of exercising good deeds. In the same context of praying to God, no matter what status a man holds, a human being is entitled to practice their beliefs. This concept applied in eliminating VAW as well; no matter what status a man holds - both financially and socially - a man is never justified to do violent acts, as well as choosing to be silent when they witness or acknowledge GBV happened.

Aside from religious perspective, WCCC also facilitate a representative of Pacific men inauguration group, Melkie Anton, to lead the training on the next day, ${ }^{27}$ taking the activism role of Track 6. He gave a challenge to participants in looking back on how the culture and religion sector in Tonga that generally

\footnotetext{
${ }^{25}$ Women and Children Crisis Centre. (2018, May 11). WCCC Media Release - Male Advocacy Stage 2 Training on Ending Violence Against Women and Girls, 21 August 2017. Retrieved from https://www.tongawccc.org/media-release-maleadvocacy-training-stage-2-on-ending-violenceagainst-women-and-girls/ 26 Ibid.

27 Ibid.
} 
accepted by common society is actually leads to normalization of gender discrimination. The instance can be seen to the phenomenon of how Tongan bride usually obliged to prove her virginity before the marriage take place, for religion purpose.

Accompanied by counseling staff of WCCC, the participants were given an outrageous insight regarding coercive control on the subsequent session. The discussion focused on abuse, intimidation, control, and isolation. Due to the notion that these kinds of acts are prevalent, most of them did not realize the impact of pressure against women. Then on the last day, WCCC Director 'Ofa GuttenbellLikiliki explained the anomaly between comprehension of intercourse topics with the recorded data. As the sexual activity topics considered taboo and pure, which restricted to be discussed by married couple only, unwanted pregnancy data - in contrast - shows increased percentage. ${ }^{28}$ WCCC used their role within the last couple session to bring new perspectives of what most Tonga population accepted as normal, while on the other side considered a violation of human rights.

From the implementation of this program, it can be seen that MTD actors involved are; Nongovernmental/ Professional (Track 2), represented by WCCC; Activism (Track 6), represented by personnel of Pacific men inauguration group; Religion (Track 7), represented by Church Leader of Tonga; and Funding (Track 8), represented by PWNAVAW.

\section{“My Body! My Rights!” in Tonga}

Focused on empowering young girls as well as upholding the commitment in eliminating VAW in Tonga, Talitha Project Incorporation - or Talitha Project for short - implementing their project titled 'My Body! My Rights!' that lasted

${ }^{28}$ Ibid. years. Firstly initiated in the 2013, this project targeting adolescent girls and young women ranging from 10 to 19 years old, with various types of activities conducted. ${ }^{29}$ The activities referred to reproduction seminar, self-defense classes, financial literacy training, and mentoring, sharing session with parents, along with other confidence building sessions. ${ }^{30}$ The purpose of Talitha Project as Track 2 is no other than supporting positive changes in social norms through interventions, which include primary prevention approaches.

The project aims in helping young girls recognizing their rights, identifying violence, and determining decision with decent mindset. For example, participants of financial literacy training with the Bank of South Pacific (BSP) are reckoning the importance of savings and financial independence, as they learned budgeting technique. ${ }^{31}$ Aside from economic aspect, the participants also encouraged to participate as advocates of change and contribute to the world development.

The message from their purpose was delivered through 'Girls Leading Our World (GLOW)' Camp as well. The camp invited the girls to see the link between Sustainable Development Goals (SDGs) with their lives. Discussing SDG5 (Gender Equality) and SDG16 (Peace, Justice, and Strong Institutions), the girls realized how they should take the role in improving participation of women. Whether it is in the parliament, when playing non mainstream sports, volunteering in society, being vocal in church, or even changing the law regarding land

\footnotetext{
${ }^{29}$ Interview with Vanessa Heleta, Director of Talitha Project, on 1 June 2018, via e-mail.

${ }^{30}$ Pacific Women. Pacific Women Annual Progress Report 2016-2017 (pp. 79). Suva: Australian High Commissioner to Fiji. 2017.

${ }^{31}$ Pacific Islands Report. (2018, May 15). 30 Tongan

Girls Complete Bank of South Pacific Financial Literacy Program, 5 May 2017. Retrieved from http://www.pireport.org/articles/2017/05/02/30tongan-girls-complete-bank-south-pacific-financialliteracy-program
} 
possession. ${ }^{32}$ Not only SDGs, the camp education material also enriched by cyber bullying seminar from CEO of Digicel, explaining how to use internet wisely as it is a powerful tool to advocate many issues.

Pioneer of feminist media in Pacific, femLINKpacific, is also taking part in spreading the word about GLOW Camp through discussion session in their radio. Previously, femLINKpacific has been actively engaged with Talitha Project in facilitating open discussions on gender topic. ${ }^{33}$ Media initiative highlighting gender equality effort indirectly gives larger impact of this project, to not only reaching the youth but also the audience of femLINKpacific itself.

From the implementation of this program, it can be seen that MTD actors involved are; Nongovernmental/ Professional (Track 2), represented by Talitha Project; Business (Track 3) represented by BSP and Digicel; and Communications and the Media (Track 9) represented by femLINKpacific.

\section{Conclusion and Recommendation}

GBV as a form of gender discrimination has become the biggest factor in decreasing women participation within many sectors of life, specifically social-economic. Based on the elaboration in the previous sections, this writing showed numerous gender equality problems in Pacific. Common understanding among the society that is still not gender sensitive; opportunities, obligation, and rights that should be more fair between men and women; early gender education; as well as policy implementation and operational services from civil servants in responding to GBV, still marked

\footnotetext{
${ }^{32}$ Loop Tonga. (2018, May 15). Tongan girls encouraged to achieve goals at Camp GLOW, 16 December 2017. Retrieved from http://www.looptonga.com/tonga-news/tongan-girlsencouraged-achieve-goals-camp-glow-71196

${ }^{33}$ Interview with Vanessa Heleta, 2018.
}

as 'homework' to be managed by governments in the Solomon Islands, Samoa, Tonga, and even other Pacific Islands countries. In doing so, international relations actor - which resembled as nine tracks in MTD - came to assist.

Although not engaged in one program simultaneously, it can be seen that the whole tracks in MTD are actively responding VAW issues in Pacific through several separated projects under Pacific Fund. Track 1 with CSSI; Track 2 with SVSG, UN Women Pacific, FSC, WCCC, and Talitha Project; Track 3 with BSP, Digicel, and Bluesky; Track 4 with Samoan 400 area representatives and Solomon Islands' five local actors; Track 5 with eight schools in Honiara; Track 6 with Samoan 25 trained counselors, CSSI's training volunteers, and Pacific men inauguration group; Track 7 with Church Leader of Tonga; Track 8 with PWNAVAW; and Track 9 with femLINKpacific. Each and every MTD actors above were allocating their resources to take the part in fighting gender equality as a collective effort to preserve world peace. With different portion adjusting to their own resources and capacity, they are addressing the same message; gender equality and peacemaking.

Peacemaking in this context embodied through their participation in the Pacific Fund to help the programs runs accordingly. The MTD actors put their respective concerns, interests, and efforts into the programs they are related to, indirectly striving to preserve the world peace through gender equality.

The existence of UN Women and Australian Government as the prominent actors with their funding, to the personal involvement of civil society in the smaller scale projects, is the evidence that this diplomacy can done by anyone, to reach out everyone in all level. The development of diplomacy brings other actors outside the government bubble, although the role of state and its national interest are inevitable to be engaged in the execution. In this context, the 
non-governmental actors are helping UN Women and Australian Government to achieve their interest, gender initiative and women empowerment.

To conclude, implementation of MTD by Australian Government and UN Women in response of VAW issue in the Pacific come in the form of community outreach programs under Pacific Fund. It is reflected from identification of MTD actors whom participated in the programs under Pacific Fund, that in line with the sole purpose of MTD itself, using respective instruments for peacemaking.

From this paper, a better understanding of the GBV situation in Pacific is presented. Although many parties have gradually making progress and impact, research regarding VAW issue should be continued on. This writing showed that raising awareness about VAW, particularly in the Pacific area, is important as they still have the entrenched social norms that devaluating women, and thus allowing GBV in practice.

\section{References}

Book

Diamond, L., \& McDonald, J. (1996). Multi

Track Diplomacy: A Systems Approach to Peace. West Hartford: Kumarian Press.

\section{Journal}

Valentina, A. M., \& Dewi, E. A. (2017). Implementasi CEDAW tentang Penghapusan Diskriminasi Perempuan: Studi Kasus Pemilu di Indonesia Tahun 2009 dan 2014. Jurnal Ilmiah Hubungan Internasional, 1-15.

\section{Official Document}

Australia Department of Foreign Affairs and Trade. (2016). Gender Equality and Women's Empowerment Strategy.
Barton: Commonwealth of Australia, DFAT.

Bricknell, R. (2015). Eliminating Violence against Women in Asia Pacific: It's All of Our Responsibility. UN Women National Committee Australia.

Fairbairn-Dunlop, P., \& Lievore, D. (2007). Pacific Prevention of Domestic Violence Programme: Tonga Report. Wellington: Pacific Prevention of Domestic Violence Programme.

Pacific Women. (2017). Pacific Women Annual Progress Report 2016-2017. Suva: Australian High Commissioner to Fij.

Turnbull, B. (2011). Independent Evaluation Report. Wellington: Pacific Prevention of Domestic Violence Programme.

UN Women. (2015). How to Design Projects to End Violence Against Women and Girls: A step-by-step guide to taking action. Toolkit.

UN Women. (2015). The Pacific Regional Ending Violence against Women Facility Fund Project Brief. Suva: UN Women Fiji Multi-Country Office.

\section{Video}

United Nations. (2015). Solomon Islands: Uprooting Violence against Women [Short Video].

\section{Website}

Loop Tonga. (2017, December 16). Tongan girls encouraged to achieve goals at Camp GLOW. Retrieved May 15, 2018, from http://www.looptonga.com/tonganews/tongan-girls-encouraged-achievegoals-camp-glow-71196

Ma'a Fafine mo e Famili Tonga. (2010). National Study on Domestic Violence for 
Tonga. Retrieved from

https://mfftonga.wordpress.com/2012/08

/27/national-study-on-domestic-

violence-for-tonga/

National Parliament of Solomon Islands. (2014).

Parliament Passess the Family

Protection Bill 2014. Retrieved from

http://www.parliament.gov.sb/index.php

$? \mathrm{q}=$ node/819

Pacific Islands Report. (2017, May 5). 30

Tongan Girls Complete Bank of South

Pacific Financial Literacy Program.

Retrieved May 15, 2018, from

http://www.pireport.org/articles/2017/05

/02/30-tongan-girls-complete-bank-

south-pacific-financial-literacy-program

Pacific Women. (2006, December 30). Samoa

Family Health and Safety Study .

Retrieved from

https://pacificwomen.org/research/samoa

-family-health-and-safety-study/

Sam, L. A. (2017, February 7). Setting the stage to break the cycle of violence: theatre as an advocacy tool for youth in Solomon Islands. Retrieved May 7, 2018, from http://asiapacific.unwomen.org/en/newsand-events/stories/2017/02/setting-thestage

UN Women. (2017, January 19). Australia and UN Women reaffirm partnership. Retrieved from UN Women Website: http://www.unwomen.org/en/news/storie s/2017/1/announcer-australia-and-unwomen-reaffirm-partnership

UN Women Asia and the Pacific. (2013,

November 17). Samoan helpline save lives. Retrieved from UN Women Asia and the Pacific Website:

http://asiapacific.unwomen.org/en/newsand-events/stories/2013/11/samoanhelpline-saves-lives
Women and Children Crisis Centre. (2017, August 21). WCCC Media Release Male Advocacy Stage 2 Training on Ending Violence Against Women and Girls. Retrieved from WCCC Website: https://www.tongawccc.org/mediarelease-male-advocacy-training-stage-2on-end 